\title{
The Eco-Island Trap: Climate Change Mitigation and Conspicuous Sustainability
}

\section{Introduction}

Conspicuous sustainability, referring to engagement in symbolic sustainability initiatives whether or not they contribute to sustainability processes, has become a popular development strategy for small islands worldwide. Drawing upon island examples from around the world, we argue that conspicuous sustainability is both counterproductive to efforts at global sustainability and risks subjecting islands to unrealistically high environmental standards, at the expense of more pressing needs.

Islands invite symbolism: They are uniquely 'subject to dream and nightmare' (Gillis 2007) and attractive as 'detached, self-contained entities' with clear boundaries (King 1993, 14). This boundedness contributes to islands' conceptualisation and iconicity, to their compelling 'lure' (Baldacchino 2012a) as places of calm, refuge, and splendid isolation. Although many islanders resist having their (often-troubled) communities labelled as paradises, many other islanders internalise the stereotype (Baldacchino 2008).

The dream of the island paradise is accompanied by the nightmare of alleged island vulnerability (Philpot et al. 2015). As Baldacchino $(2008,46)$ states: 'Islanders are often portrayed in the metropolitan press as victims of tragic circumstances beyond their control, fitting easily into stereotypes of dehistoricized vulnerability and "paradise in peril".' Challenges include economic disadvantages, corruption and bad governance, military or tourist invasion, and exploitation by large corporations. Islands, like many other locations, indeed experience these risks, but just as the boundedness of small islands makes their beauty more graspable, so too does it set their disasters in relief, transforming islands into symbolic carriers for mainland fears. This is evident with regards to climate change. Islanders may themselves exploit the visibility of climate change impacts for political gain (Baldacchino and Kelman 2014; Kelman 2014), but there are risks to their symbolic self-representation as a 'canary in a coalmine': After all, the role of the canary (islanders) is to die on behalf of the miners (everyone else) (Farbotko 2010, 54).

Island studies researchers have challenged the homogenisation of the island image (Ronström 2012), criticising 'hackneyed notions and flashy brandings of islands: as isolates, cut off from the mainstream; as innocent, protected from the ravages of modernity; [...] as pristine and particularly environmentally conscious societies; as ecosystem quirks, extremely unstable and vulnerable' (Baldacchino and Clark 2013, 129). Yet small island boundedness grants exceptional geographical legibility and comprehensibility, making islands susceptible to social and political manipulation (Baldacchino 2012b; Grydehøj 2011). Islands are manageable spaces in which powerful actors can more easily implement policy, identify the policy's results, and show these results to others.

We argue that spatial manageability and visions of island paradise and vulnerability combine to encourage a form of conspicuous sustainability in small island communities worldwide. Islanders and their governments - at the local level and above - seek to transform places into "ecoislands", engaging in renewable energy and sustainable development initiatives partly to capitalise on their symbolic value and visibility. Although potentially beneficial, such strategies risk placing island communities in an "eco-island trap". Pursuit of iconic sustainability may raise 
costs without raising income, distract from more pressing social and environmental concerns, contribute to a dangerous marketisation of environmental responsibility, and provide green cover behind which communities elsewhere (or on the island) can maintain unsustainable practices.

\section{Conspicuous sustainability}

This paper focuses on initiatives undertaken in the name of sustainability and climate change mitigation that also seek to gain competitive advantage, strengthen sustainable tourism or ecotourism, claim undue credit, distract from failures of governance, or obviate the need for more comprehensive policy action. We term such behaviour "conspicuous sustainability" inasmuch as the initiative's value lies substantially in its visibility, iconicity, and symbolism rather than in the environmental benefits it produces. Instances of conspicuous sustainability often genuinely enhance sustainability or self-sufficiency in small but direct ways while nevertheless harming the cause of sustainable development and climate change mitigation more generally.

It is not that islanders seek to deceive people or damage the environment; rather, the power of island symbolism is that both islanders and mainlanders tend to mentally enlarge the impact of island sustainability initiatives beyond their actual contributions. Furthermore, islanders may imagine that what they see as side-benefits to promoting sustainability (positive place brand, advantages in attracting tourists, enhanced diplomatic power) represent value added, when in fact these side-benefits can transform over time into the primary rationale for such initiatives. Innocuous initiatives (renewable energy systems, recycling, ecological footprint reduction) can be made conspicuous through explicit branding exercises. Some sustainability initiatives are conspicuous from conception, for instance projects involving high visibility (foregrounding sustainability infrastructure) and impressive "green-looking" architecture.

The linking of sustainability initiatives with sustainable tourism or ecotourism is frequently indicative of conspicuous sustainability. Tourism is an important industry for many islands (Baldacchino and Ferreira 2013), and ecotourists are regarded as particularly valuable island visitors (d'Hauteserre and Funck 2016). Sustainable tourism and ecotourism are themselves contested due to their own contribution to climate change (Maguigad et al. 2015), with assessments of tourism sustainability typically requiring the externalisation of greenhouse gas emissions resulting from transport while trying to reconcile the often excessive on-island resource use by tourists. When Chongming Island, China was aiming to develop itself as an ecoisland, ecotourism and eco-agriculture (for both climate change mitigation and adaptation) were seen as the main pathways to success, with recognition that tourism itself might preclude it from becoming an eco-island (Huang et al. 2008).

\section{Competitive sustainability}

In today's world of financialised environmentalism and ecosystem services (Robertson 2012), sustainability is competitive. Environmental goods are attributed precise (though not necessarily accurate) monetary values, and places represented as especially sustainable may benefit from increased positive brand recognition and incoming investment, tourists, and diplomatic power. There is a pre-existing and advantageous generic island brand of pristine nature combined with assumed slower and more traditional ways of life (Baldacchino 2010). People thus often imagine 
islands to be environmentally friendly even without sustainability-promoting initiatives. When such endeavours are undertaken, island status enhances their visible efficacy.

Small population and economic size might inhibit island communities from developing economies of scale (Grydehøj 2011), but they make it easier to achieve superlative environmental sustainability. It is easier to become an eco-island than an eco-mainland. Even a massive mainland windfarm will supply just a small part of a large country's total energy consumption, yet a handful of wind turbines or a single solar power facility can potentially fulfil all of the energy needs of a small community - whether or not this community is located on an island. Island boundedness makes it easy to conceptualise and communicate energy selfsufficiency.

The Danish islands of Ærø and Sams $\varnothing$ both market themselves as $100 \%$ renewable, while far larger renewable energy production systems located in mainland Danish municipalities (such as the offshore windfarms south of Lolland) do not lead to local reputations for sustainability. Tellingly, both Ærø and Sams $\varnothing$ claim to be the only $100 \%$ renewable/sustainable island in Denmark, highlighting the competitive aspect of this designation for attracting tourists and new residents as well as selling 'sustainable' island products. The brand value added by $100 \%$ renewable status decreases when another island shares this status.

Numerous small island states and subnational island jurisdictions compete to be at the forefront of introducing renewable energy. Both Sams $\varnothing$ (Spear 2014) and Scotland's Isle of Eigg (Geoghegan 2014) claim to be the first sole fully renewable island. El Hierro, in the Canary Islands, explicitly competes by 'billing itself as the world's first energy self-sufficient island that has never been hooked up to a power grid,' in contrast to Samsø, which 'is also energyindependent, but was previously hooked up to the Danish grid and didn't make the change in isolation' (Frayer 2014). The Isle of Wight's Eco Island project aims for the island to 'become known for its eco-tourism' and 'to have the lowest carbon footprint in England by 2020' (Island Strategic Partnership 2008, 12). At the sovereign state level, Dominica aims for $100 \%$ renewable energy production by 2016, 'leading the way in the Caribbean in realising renewable energy goals' (Government of the Commonwealth of Dominica, 2014). Tokelau claims to be 'the world's first truly renewable energy nation' (Government of Tokelau n.d.), yet already in 2009 the Maldives announced it would be the first fully renewable country in the world (Clark 2009). Taiwan seeks to compete for sustainability on an international level by designating four of its islands and archipelagos (Penghu, Kinmen, Green Island, Xiaoliuqiu) as "Low Carbon Islands".

Like the Maldives, many islands claim credit for sustainability initiatives before carrying them out. Hawaii has been praised as America's first fully renewable state 'in the three-way race among states for the title of national clean-energy champion' (Salter 2015), despite Hawaii's roll-out plan only seeking to achieve 100\% renewable energy by 2045 . Even El Hierro, which is frequently discussed as having already achieved full energy sustainability, is trading on a potential future reality: The island still depends on a diesel power station, and its slowly developing mixed wind and hydropower renewables system is extremely costly to construct and has potentially come at the expense of developing the island's tourism economy (Pitt 2015). Perceptions of island sustainability are subjective, with economic and environmental sustainability sometimes existing in an uneasy balance (Graci and Dodds 2010). 
From a global perspective on climate change mitigation, none of these cases make much of an impact. Although supplying Samsø's 3,800 residents with renewable energy is commendable, it is insignificant relative even to Denmark's greenhouse gas emissions. Small island renewable energy systems may sometimes be helpful for local climate change adaptation through developing self-reliance for dealing with short-term or long-term crises (in effect, disaster risk reduction), but they mean little in terms of climate change mitigation. Furthermore, the poor economies of scale, high transport costs, and other economic disadvantages experienced by small islands suggest that, were the same money spent on increasing renewable energy production capacity on the mainland, it could potentially yield significantly greater absolute results. Renewable energy initiatives in places like Samsø may be more visibly effective but less operationally effective in terms of actually producing energy.

\section{Eco-vanguardism}

Sustainability initiatives can sometimes transform into an eco-vanguardism that produces an allconsuming policy framework. Martin $(2012,160)$, for example, recommends that Greenland forego traditional development strategies and instead become 'the political and creative avantgarde of an emergent post-growth and post-carbon movement, eventually giving to the world not raw materials, but ideas and practices for the realization of innovative social, political and economic organization.' Islands that buy into their own public relations risk disappearing down a rabbit hole of sustainability discourse.

For instance, the organisers of the 2015 Sams $\varnothing$ Sustainable Festival state: 'On Samsø, sustainability is not just something that is spoken about. It's a real and living part of daily life, with a new LNG ferry, wind turbines, and municipal electric cars. The island is in many ways already a frontrunner within renewable energy and is following an ambitious plan to be fossilfree by 2030 at the latest' (Samsø Bæredygtig Festival 2015; translation our own). Small island spatiality makes energy production and consumption more quantifiable, but "sustainability" itself can become a simultaneously unrealisable and dominating goal. Greenland is being urged to revolutionise the world, and Sams $\varnothing$ is investing in the diminishing returns of incremental sustainability gains.

Regardless of whether pursuit of eco-island status is a good idea from a local perspective, more thought must be given to the assertion that eco-islands are models for larger and wider sustainability initiatives. Eco-island supporters often argue that they are setting an example for the rest of the world. Although the large number of self-proclaimed eco-islands worldwide does suggest that such initiatives inspire other islands to pursue sustainability initiatives, it is unclear whether this role model effect extends beyond islands. The dynamics of competitive sustainability are such that symbolic victories on small islands are likely to be leveraged by those actors which can conceivably take credit for them (such as Denmark's national government in the case of Sams $\varnothing$ ), thereby reducing pressure for further climate action. Competitive sustainability likewise benefits first movers, dissuading latecomers from undertaking similar actions. That is, by exploiting islandness to make sustainability competitive, places like Sams $\emptyset$ relatively devalue the environmental goods themselves while claiming exclusive rights to the reputational goods. 
The very manageability that accompanies island spatiality and makes eco-status achievable advocates against the extension of sustainability initiatives beyond clearly demarcated spatial limitations, for doing so renders the eco-island geographically illegible, smashing the illusion of self-contained sustainability. Once eco-island boundedness is breached, complicating variables come into play, making sustainable status more difficult to communicate. Small island communities are thus unlikely to serve as practical models for mainland sustainability but are exceptionally likely to be tokenised by mainland economic and political interests. This is not to say that islands should not utilise renewable energy or otherwise contribute to climate change mitigation, but it does suggest that triumphant proclamations of eco-island status may be counterproductive from the perspective of combatting climate change and seeking sustainability.

Even if eco-islands were scalable and succeeded in influencing mainland communities, this influence might not prove positive. Researchers increasingly emphasise the environmental benefits of high-density urban environments, and assuming current or increased human population levels, sustainable cities and vertical urbanism (rather than low-density communities and the urbanisation of nature) seem necessary for global-scale sustainability, including climate change mitigation, adaptation, and their connections. Small eco-islands may be role models, but they are not the kind of role models that the world needs most. Localised self-sufficiency does not necessarily contribute much to global sustainability.

\section{Eco-island traps}

Not only is conspicuous sustainability of uncertain environmental good, but pursuing it risks placing island communities in eco-island traps: being trapped by the label and trapped into being exemplars.

\section{Trapped by the label}

Efforts towards renewable energy are needed, commendable, generally cost-effective, and a necessary part of the drive toward environmental friendliness, climate change mitigation, and sustainability. It has even been argued that when islands undertake 'innovative approaches to developing sustainable economic activities and utilization of the latest environmental technologies to combat climate change then there is a corresponding upsurge and celebration of cultural awareness' (Global Islands Network n.d.). Not all approaches are advantageous, however, so implementation must be considered carefully. Marconnet (2007) details how renewable energy systems are recommended for remote Pacific islands to replace inefficient and unreliable diesel generators, yet many photovoltaic initiatives have failed due to poor maintenance. For routine maintenance or repair, technical experts and parts tend to be needed from the mainland or farther afield. If transport difficulties ensue, electricity shortages may arise. These problems are the same for both renewable and non-renewable sources, and the solutions are similar in terms of training and employing islanders for operations and maintenance while keeping spare parts available. Consequently, full life-cycle analyses must be conducted for each situation to determine whether a renewable system would be easier and cheaper to operate and maintain than a non-renewable system. Supply chains might be better or worse for diesel compared to batteries for solar cells, depending on specific locations.

Meanwhile, the most common land-based renewable energy sources face practical problems on small islands. Active solar, wind power, and short-rotation biomass crops require tracts of land, 
which might be unavailable on small islands. In the Pacific, most land is owned and used in accordance with tradition (Chapelle 1978), prompting difficult negotiations for turning it over to community energy needs (see also Niles and Lloyd 2014). Hydropower is not an option for the many small islands that lack flowing freshwater. Biomass systems, such as composting, may be unviable because the odour would permeate the entire island.

Marine energy generation (including wind, solar, wave, and tidal energy) involves increased difficulty in operation and maintenance, including salt corrosion and lack of access during storms. Other options are feasible, such as micro-solar and/or micro-wind serving each structure individually or small-scale solar energy pumping water up to a tower, which then generates electricity as it falls - provided that training and spare parts are available. This does not preclude island renewable energy, but it does highlight that implementation must overcome significant drawbacks and that renewable energy does not necessarily mean self-sufficiency.

The assumption of the utopic nature of renewable energy has appeared in island communities aiming for an eco-label. The island of Fetlar (population around 80) in Shetland, Scotland proudly introduced its electric bus in 2013 as part of going green (Marter 2013), but because the wind-based energy to recharge the bus battery was not yet in place, the electric bus remained reliant on main grid electricity. Although the bus encouraged Fetlar's goal of carbon neutrality, its main purpose was to transport people to and from the ferry terminal, the ferries for which run on fossil fuels.

These observations are not to denigrate the aim of sustainability. Each small step counts toward the overall goal, and not all eco-approaches can be achieved simultaneously or perfectly. Our criticism focuses on conspicuous sustainability. The discourse surrounding Fetlar's electric bus was about proving eco-credentials (Marter 2013), whether or not these were yet satisfied. Environmental friendliness is becoming more important in word than deed, but explanations of local conditions are being bypassed in favour of an overemphasis on the small (and often positive) steps being taken.

Conspicuous sustainability can override and distract from basic social, economic, political, and environmental concerns in island communities. Dodds (2012) explains how Tofino, British Columbia has positioned itself as a sustainable tourism/ecotourism destination and made progress in generating local tourism livelihoods but also underlines fundamental challenges for Tofino that remain unaddressed, including freshwater shortages, negative impacts of second homes on island life, and land use conflicts. The resolution of such basic problems could give sustainable livelihoods, including tourism, far greater chances of success. Yet Tofino focuses on marketing the eco-label to outsiders rather than implementing it from the ground up.

\section{Trapped into being exemplars}

Many islands adopt the status of sustainability exemplars without considering the full implications or feasibility. In 2012, Dominica labelled itself 'amongst the few nations that can be termed "carbon neutral"" (CIF 2012) and committed itself to being carbon negative by 2020 (Williams 2014). Dominica's commitments prior to the 2015 international climate change negotiations in Paris (Commonwealth of Dominica 2015) do not mention carbon neutrality or carbon negativity but lament the increase in sports utility vehicles (SUVs) in the country from 
2005-2014, which contributed to a near-doubling of transport sector greenhouse gases, despite high import taxes. Proposals to encourage hybrid vehicles are calculated to reduce transport sector emissions by just 17\% (Commonwealth of Dominica 2015), failing to offset the SUVrelated increase.

Despite considerable efforts, Dominica has been disappointed in its desire to become a lowcarbon sustainability exemplar. The country relies on protected areas as carbon sinks (CIF 2012; Commonwealth of Dominica 2015), which cannot keep up with demand for fossil fuels. These protected areas and Dominica's ecotourism reputation also attract tourists, who mainly arrive via cruise ships, which the government accepts are major contributors to greenhouse gas emissions (Commonwealth of Dominica 2012).

Similarly, when Mohamed Nasheed was elected President of the Maldives in 2008, ending three decades of dictatorship, he highlighted his country's climate change-related suffering and offered the Maldives as an exemplar for climate change mitigation. One promised goal was a carbon neutral country by 2020 (Williams 2014). The Maldives' national carbon audit for 2009 (Bernard et al. 2010) shows that the most carbon-intensive industry is tourism, a pillar of the country's economy, causing 36\% of the Maldives' internal carbon equivalent emissions. Next comes electricity generation at $19 \%$. Emissions from international flights bringing in tourists approximately equal all domestic emissions (Bernard et al. 2010). Without significantly curtailing tourism, including yachts and cruise ships, the Maldives is unlikely to achieve carbon neutrality.

King Island, Tasmania brands itself as a pristine environment (Khamis 2010). Ironically, the island's sustainability credentials are promoted through its bottled water product, named Cloud Juice and marketed as "Supremely Pure Rainwater". As with Fiji's promotion of bottled water in support of sustainability (Reddy and Singh 2010), bottled water is in many ways antithetical to sustainability, given the high energy and other environmental costs of the bottles and product transportation (Gleick and Cooley 2009; Wilk 2006). Yet the product exemplifies these islands' eco-labels.

Despite island attempts at becoming sustainability role models, the mainland tends to view ecoislands as good places for sustainable tourism or ecotourism rather than seeking to emulate and improve its own sustainability practices. Islands were among the first countries to highlight climate change politically, with the Small States Conference on Sea Level Rise held in Malé, the Maldives in November 1989 (http://www.islandvulnerability.org/slr1989.html), even before the two main UN processes on climate change (Intergovernmental Panel on Climate Change and UN Framework Convention on Climate Change) had issued their first reports. Since then, small island developing states (SIDS) such as Dominica and the Maldives have continually highlighted their vulnerability to climate change impacts and pushed for substantive action. Nevertheless, the latest international climate change agreement, signed in Paris in December 2015, is mainly voluntary, has a long implementation timeframe, and includes country commitments for greenhouse gas reductions that fail to meet the agreement's own targets for global mean temperature rise. 
Where does this leave eco-islands? They are trapped as exemplars, struggling to meet potentially unrealisable expectations they have foisted upon themselves. Eco-islands rarely fulfil their own eco-goals and appear to have minimal impact on convincing the rest of the world to pursue similar goals.

\section{Conclusion}

This paper has developed "conspicuous sustainability" in theory and shown its emergence in island communities in practice. Islanders can embrace visions of island paradise and vulnerability to capitalise upon the symbolism and visibility of eco-island status. These strategies have benefits and should not be denigrated en masse. Many eco-island initiatives, however, compound vulnerabilities without tackling them, creating traps of their own devising. Pursuing iconic sustainability, irrespective of real results, has negative consequences that may spiral out of control, causing more problems than it solves.

Ultimately, our analysis of conspicuous sustainability is a plea for realism. Island communities seeking to become exemplars may end up believing in and seeking to conform to their own rhetoric, irrespective of the cost. As such, conspicuous sustainability parallels how some island communities strive to adhere to island stereotypes (in effect, conspicuous islandness) without critiquing the implications of attaining these traits or the implications of matching them in reality (Baldacchino 2005; Grydehøj et al. 2015).

Dilemmas are also present in the emergence of divergent, mutually exclusive pathways to sustainability. Fernando de Noronha, Brazil sports many sustainability initiatives, usually enacted by individuals. Residents collect rainwater for vegetable gardens; use natural ventilation to keep homes cool; and use the presence of tourists, who wish to witness baby sea turtles hatching and scrambling for the ocean, to scare away birds that would normally feast on the turtles exposed on the beach. The debate regarding increasing tourism-related income to maintain island livelihoods is whether to cater for mass tourism (with a larger market but with each tourist spending less money) or aim for high-end tourism (with a smaller market but with each tourist spending more money). The relative advantages and disadvantages are well-known in the literature, as is the challenge of catering to multiple markets in a small environment (Graci and Dodds 2010). Discussions on Fernando de Noronha expose differences of opinion yet display realism as to what the island can and cannot offer.

Island communities should never hesitate to promote their real advantages, experimenting and tinkering with sustainability in various forms. Renewable energy, sustainability initiatives, and policy innovations that are cost-effective, locally appropriate, and are beneficial to the community will often be worth pursuing. An initiative that might be overly conspicuous in one context (accompanied by one branding or ecotourism marketing strategy) might be sensible in another context. Island policymakers and stakeholders would benefit from reflecting upon the ultimate motivations behind and goals for sustainability initiatives. Recognising the boundedness and heterogeneity of islands, accepting that paradise and vulnerability are icons, yet do exist and do meld, means that sustainability can be enacted without it being merely symbolic - if locals and visitors alike are focused on reality rather than conspicuousness.

\section{References}


Baldacchino G 2012a The lure of the island: a spatial analysis of power relations Journal of Marine and Island Cultures 1 55-62

Baldacchino G 2012b Islands and despots Commonwealth \& Comparative Politics 50 103-120

Baldacchino G 2010 Island brands and 'the Island' as a brand: insights from immigrant entrepreneurs on Prince Edward Island International Journal of Entrepreneurship and Small Business 9 378-393

Baldacchino G 2008 Studying islands: on whose terms? Some epistemological and methodological challenges to the pursuit of island studies Island Studies Journal 3 37-56.

Baldacchino G 2005 Islands: objects of representation Geografiska Annaler, Series B: Human Geography 87 247-251

Baldacchino G and Clark E 2013 Guest editorial introduction: islanding cultural geographies Cultural Geographies 20 129-134

Baldacchino G and Ferreira E C D 2013 Competing notions of diversity in archipelago tourism: transport logistics, official rhetoric and inter-island rivalry in the Azores Island Studies Journal 8 84-104

Baldacchino G and Kelman I 2014 Critiquing the pursuit of island sustainability: blue and green, with hardly a colour in between Shima 8 1-21

Bernard F, Khelil T B, Pichon V, and Tissot L 2010 The Maldives'2009 Carbon Audit BeCitizen, Paris

Chapelle A T 1978 Customary land tenure in Fiji: old truths and middle-aged myths Journal of the Polynesian Society 87 71-88

CIF 2014 Dominica: Low-Carbon Climate-Resilient Development Strategy 2012-2020 CIF (Climate Investment Funds), Washington, DC

Clark D 2009 Maldives first to go carbon neutral The Guardian 15 March (http://www.theguardian.com/environment/2009/mar/15/maldives-president-nasheed-carbonneutral) Accessed 4 January 2016

Commonwealth of Dominica 2012 Second National Communication of the Commonwealth of Dominica Under the United Nations Framework Convention on Climate Change Government of the Commonwealth of Dominica, Roseau

Commonwealth of Dominica 2015 Intended Nationally Determined Contribution (INDC) of the Commonwealth of Dominica Communicated to the Secretariat of the United Nations Framework Convention on Climate Change (UNFCCC) on the 30th September, 2015 Government of the Commonwealth of Dominica, Roseau 
d'Hauteserre A M and Funck C 2016 Innovation in island ecotourism in different contexts: Yakushima (Japan) and Tahiti and its Islands Island Studies Journal 11 227-244

Dodds R 2012 Sustainable tourism: a hope or a necessity? the case of Tofino Journal of Sustainable Development 5 54-64

Farbotko C 2010 Wishful sinking: disappearing islands, climate refugees and cosmopolitan experimentation Asia Pacific Viewpoint 51 47-60

Frayer L 2014 Tiny Spanish island nears its goal: 100 percent renewable energy NPR 28 September (http://www.npr.org/sections/parallels/2014/09/17/349223674/tiny-spanish-islandnears-its-goal-100-percent-renewable-energy) Accessed 4 January 2016

Geoghegan P 2014 The 'greenest' island in the world? Al Jazeera 29 January (http://www.aljazeera.com/indepth/features/2014/01/greenest-island-world201412783012455475.html) Accessed 4 January 2016

Gillis J R 2007 Island sojourns Geographical Review 97 274-287

Gleick P H and Cooley H S 2009 Energy implications of bottled water Environmental Research Letters 4014009.

Global Islands Network n.d. 'Green Island Case Studies'. http://www.globalislands.net/greenislands/

Government of the Commonwealth of Dominica 2014 Dominica to be $100 \%$ Renewable by 2016 Government of the Commonwealth of Dominica (http://news.gov.dm/index.php/news/1918-dominica-to-be-100-renewable-by-2016) Accessed 4 January 2016

Government of Tokelau n.d. Solar project (http://www.tokelau.org.nz/Solar+Project.html) Accessed 4 January 2016

Graci S and Dodds R 2010 Sustainable Tourism in Island Destinations Earthscan, London Grydehøj A 2011 Making the most of smallness: economic policy in microstates and subnational island jurisdictions Space and Polity 15 183-196

Grydehøj A, Pinya X B, Cooke G, Doratlı N, Elewa A, Kelman I, Pugh J, Schick L and Swaminathan R 2015 Returning from the horizon: introducing Urban Island Studies Urban Island Studies 1 1-19

Huang B, Ouyang Z, Zheng H, Zhang H, and Wang X 2008 Construction of an eco-island: A case study of Chongming Island, China Ocean \& Coastal Management 51, 575-588 
Island Strategic Partnership 2008 Eco Island Island Strategic Partnership, Newport

Kelman I 2014 No change from climate change: vulnerability and small island developing states The Geographical Journal 180 120-129

Khamis S 2010 An image worth bottling: the branding of King Island Cloud Juice International Journal of Entrepreneurship and Small Business 9 434-446

King R 1993 The geographical fascination of islands in Lockhart D G, Drakakis-Smith D, and Schembri J eds The Development Process in Small Island States Routledge, London 13-27

Maguigad V, King D, and Cottrell A 2015 Political Ecology Approach to Island Tourism Planning and Climate Change Adaptation: A Methodological Exploration Urban Island Studies 1 134-151.

Marconnet M 2007 Integrating Renewable Energy in Pacific Island Countries. Dissertation for a Master of Commerce and Administration in Economics, Victoria University of Wellington

Marter H J 2013 Shetland's first electric bus Sheltand News 26 June (http://www.shetnews.co.uk/news/7009-shetlands-first-electric-bus) Accessed 4 January 2016

Martin J 2012 Greenland as the avant-garde of post-carbon and post-growth economies? in da Rocha Sá Lima J, Hjemdal T I, Melsom A, and Brorman Jensen B, and Terroir eds Conditions: Independent Scandinavian Magazine on Architecture and Urbanism 11-12 160-166

Niles K and Lloyd B 2014 Using power sector reform as an opportunity to increase the uptake of renewable energy in the power sector: responding to peak oil and climate change in Caribbean and Pacific small island developing States, between 1970-2010 Natural Resources Forum 3814 26

Philpot D, Gray T S, Stead S M 2015 Seychelles, a vulnerable or resilient SIDS? A local perspective Island Studies Journal 10 31-48

Pitt L 2015 The greenest island in the world? BBC 5 October (www.bbc.com/news/magazine34424606) Accessed 20 October 2015

Reddy M and Singh G 2010 Branding of Fiji's bottled water: edging into sustainable consumption International Journal of Entrepreneurship and Small Business 9 447-462

Robertson M 2012 Measurement and alienation: making a world of ecosystem services Transactions of the Institute of British Geographers 37 386-401

Ronström O 2012 Finding their place: islands as locus and focus Cultural Geographies 2 153165 
Salter R 2015 With new law, Hawaii will lead the nation in clean energy Switchboard 9 June (http://switchboard.nrdc.org/blogs/rsalter/with_new_law_hawaii_will_lead_html) Accessed 4 January 2016

Samsø Bæredygtig Festival 2015 (http://samsoe-baeredygtig-festival.dk) Accessed 4 January 2016

Spear S 2014 Samso: world's first 100\% renewable energy-powered island is a beacon for sustainable communities Ecowatch 1 May (http://ecowatch.com/2014/05/01/samso-renewableenergy-island-sustainable-communities/) Accessed 4 January 2016

Wilk R 2006 Bottled water: the pure commodity in the age of branding Journal of Consumer Culture 6 303-325

Williams M 2014 From Apia to Paris Our Planet September 36-39 